\title{
UJI EFEKTIVITAS AFRODISIAKA DARI EKSTRAK ETANOL BUNGA KEMBANG SEPATU (Hibiscus rosa-sinensis L.) PADA TIKUS (Rattus norvegicus L.) PUTIH JANTAN
}

\section{(EFFECTIVENESS TEST OF THE ETHANOL EXTRACT HIBISCUS FLOWER (Hibiscus rosa- sinensis L.) AS AN APHRODISIAC OF MALE ALBINO RATS (Rattus norvegicus L.))}

\author{
KETUT AGUS ADRIANTA $^{1 \bullet}$, I GUSTI AGUNG AYU KUSUMA WARDANI ${ }^{1}$ \\ ${ }^{1}$ Akademi Farmasi Saraswati Denpasar, Jalan Kamboja No.11A, Denpasar, Bali
}

\begin{abstract}
Abstrak: Afrodisiaka adalah semua bahan baik obat dan makanan yang dapat membangkitkan gairah seksual. Di Indonesia terdapat begitu banyak bahan tanaman obat herbal alami yang dapat digunakan sebagai afrodisiaka. Salah satu tanaman yang dipercaya mempunyai khasiat sebagai afrodisiaka adalah tanaman kembang sepatu (Hibiscus rosa-sinensis L). Penelitian ini bertujuan untuk mengetahui pengaruh pemberian ekstrak etanol bunga kembang sepatu (Hibiscus rosa-sinensis L.) sebagai afrodisiaka pada tikus (Rattus norvegicus L.) putih jantan. Ekstrak bunga kembang sepatu diberikan secara oral setiap hari selama 8 hari. Terdapat 3 kelompok perlakuan yaitu kelompok kontrol yang diberikan akuades, kelompok perlakuan I diberikan ekstrak bunga kembang sepatu dengan dosis $1 \mathrm{~g} / \mathrm{KgBB}$, dan kelompok perlakuan II diberikan ekstrak bunga kembang sepatu konsentrasi $2 \mathrm{~g} / \mathrm{KgBB}$, Parameter pengukuran berupa introduction (pendekatan), climbing (menunggang), dan coitus (kawin). Hasil penelitian menunjukkan bahwa ekstrak bunga kembang sepatu dapat meningkatkan libido tikus putih jantan. Dapat disimpulkan bahwa pemberian ekstrak bunga kembang sepatu secara oral selama 8 hari efektif meningkatkan libido tikus jantan pada dosis $1 \mathrm{~g} / \mathrm{KgBB}$.
\end{abstract}

Kata kunci: afrodisiaka, bunga kembang sepatu (Hibiscus rosa-sinensis L.), climbing, coitus, introduction

\begin{abstract}
Aphrodisiac is all of the ingredients and foods that can arouse sexual desire. In Indonesia, there are so many natural herbs medicinal plant materials that can be used as aphrodisiac. One of the plants are be trusted to have efficacy of aphrodisiac is hibiscus (Hibiscus rosa-sinensis). This research was aimed to find out the influence effect of the ethanol extract of the hibiscus flower (Hibiscus rosa-sinensis L.) as aphrodisiac of male albino rats (Rattus norvegicus L.). Hibiscus flower extract was given orally daily for 8 days. The animals were divided into three groups: control group was given aquadest, the treatment group I was given the hibiscus flower extract dose $1 \mathrm{~g} / \mathrm{KgBB}$ and the treatment group II was given the hibiscus flower extract dose $2 \mathrm{~g} / \mathrm{KgBB}$. Parameter measurement comprise introduction (approach), climbing (riding), and coitus (mating). The results of the research showed that the hibiscus flower extract could increase libido male albino rats. Could be concluded that giving the hibiscus flower extract orally for 8 days with dose $1 \mathrm{~g} / \mathrm{KgBB}$ effectively increase libido male albino rats.
\end{abstract}

Keywords: aphrodisiac, climbing, coitus, hibiscus flower (Hibiscus rosa-sinensis L.), introduction.

\section{PENDAHULUAN}

Sebelum obat-obat sintetik ditemukan, masyarakat telah mengenal dan memakai tanaman berkhasiat obat yang merupakan bagian dari penyelenggaraan pengobatan tradisional. Banyak orang beranggapan bahwa penggunaan tanaman obat atau obat tradisional relatif lebih aman dibandingkan obat sintesis. Selain itu kelebihan lainnya adalah ketersediaan obat dengan segera, dan harganya yang relatif lebih murah (Widiani, 2006). Salah satu obat yang banyak diminati orang dari masa ke masa adalah obat yang berkhasiat sebagai afrodisiaka atau dalam bahasa sehari-hari disebut juga 'obat kuat' (Widiani, 2006).

Afrodisiaka adalah semua bahan (obat dan makanan) yang dapat membangkitkan gairah seksual (Pallavi et. al., 2011, dikutip dari Muslichah, 2011). Mengingat seksualitas merupakan salah satu faktor penting dan cukup peka dalam kehidupan berkeluarga, maka tak heran afrodisiaka banyak diminati khususnya di kalangan pria. Di Indonesia terdapat begitu banyak bahan tanaman obat herbal alami yang dapat digunakan sebagai afrodisiaka. Salah satu tanaman lainnya yang diduga mempunyai khasiat sebagai afrodisiaka adalah tanaman kembang sepatu. Di negara Kuwait, bagian bunga dari

\footnotetext{
• email korespondensi: agusaick@gmail.com
} 
tanaman kembang sepatu ini digunakan sebagai afrodisiaka (VM Jadhav, et. al., 2009).

Dari studi tentang tumbuhan kembang sepatu serta berbagai studi yang ada tentang afrodisiaka mendorong peneliti untuk melakukan penelitian mengenai efektifitas ekstrak bunga kembang sepatu sebagai afrodisiaka pada tikus jantan. Peneliti mengaharapkan hasil penelitian ini dapat diterima dan bermanfaat dalam bidang kesehatan, terutama dalam perkembangan pengobatan pada masalah seksual pada pria yaitu disfungsi ereksi.

Penelitian ini bertujuan untuk mengetahui efek ekstrak bunga kembang sepatu sebagai afrodisiaka pada tikus jantan.Ada dua rumusan masalah dalam penelitian ini:

1. Apakah ekstrak bunga kembang sepatu efektif sebagai afrodisiaka pada tikus jantan?

2. Berapa dosis efektif ekstrak bunga kembang sepatu yang digunakan untuk dapat memberikan efek afrodisiaka terbaik pada tikus jantan?

\section{BAHAN DAN METODE}

Rancangan Penelitian. Jenis penelitian yang dilakukan adalah penelitian eksperimental Randomized Posttest Only Control Group Design. Dimana sampel dibagi menjadi 3 kelompok yang terdiri dari 1 kelompok kontrol dan 2 kelompok uji dengan jumlah sample uji 24 tikus dengan masingmasing kelompok 8 tikus. Kelompok kontrol akan diberikan akuades. Kelompok uji 1 diberikan ekstrak etanol bunga kembang sepatu dengan dosis $1 \mathrm{~g} / \mathrm{KgBB}$. Dan kelompok uji 2 diberikan diberikan ekstrak etanol bunga kembang sepatu dengan Dosis $2 \mathrm{~g} / \mathrm{KgBB}$. Semua diberikan sebanyak sebanyak 2,5 cc dua kali sehari per tikus jantan selama 8 hari pengamatan.

Bahan. Bahan yang digunakan dalam pengujian ini adalah serbuk simplisia bunga kembang sepatu, etanol 96\%, dan akuades.

Metode. Jenis penelitian yang dilakukan adalah penelitian eksperimental Randomized Posttest Only Control Group Design dengan teknik pengumpulan data dilakukan secara observasi atau melakukan pengamatan secara langsung, serta penelusuran pustaka dengan menggunakan sumber dari jurnal penelitian dan literatur terkait. Bunga kembang sepatu segar dipanen dan dijadikan simplisia. Kemudian dimaserasi dengan menggunakan etanol 96\%. Setelahnya ekstrak etanol bunga kembang sepatu dievaporasi hingga mendapatkan ekstrak. Ekstrak bunga kembang sepatu kemudian dibagi menjadi 2 dosis yaitu dosis $1 \mathrm{~g} / \mathrm{KgBB}$, dan dosis $2 \mathrm{~g} / \mathrm{KgBB}$ Ekstrak ini akan diberikan kepada tikus jantan putih Rattus norvegicus L. yang telah melalui fase adaptasi dan telah dikelompokkan secara acak. Kemudian setelah ekstrak diberikan, ditunggu selama 15 menit dan betina dimasukkan ke dalam kandang. Amati aktivitas yang terjadi.

\section{HASIL DAN PEMBAHASAN}

Jumlah terjadinya aktivitas dari parameter pengukuran yaitu introduction, climbing dan koitus kemudian diolah dengan menggunakan SPSS. Hasil menunjukkan bahwa uji afrodisiak dilihat dari parameter introduction, climbing, dan coitus dengan nilai kemaknaan $(\mathrm{p})=0 ., 001(\mathrm{p} \leq$ $0,05)$ sehingga dapat dikatakan ada perbedaan bermakna antara kelompok kontrol dengan perlakuan, baik pada dosis $1 \mathrm{~g} / \mathrm{KgBB}$, dan $2 \mathrm{~g} / \mathrm{KgBB}$. Hasil pengamatan yang didapatkan adalah sebagai berikut:

Tabel 1. Hasil pengamatan terjadinya aktivitas dari tiap kelompok

\begin{tabular}{|c|c|c|c|c|}
\hline NO & INTRO & CLIMBING & KOITUS & KLP \\
\hline 1 & 19.0 & 18.0 & 0.0 & 1.0 \\
\hline 2 & 48.0 & 48.0 & 3.0 & 1.0 \\
\hline 3 & 23.0 & 21.0 & 1.0 & 1.0 \\
\hline 4 & 18.0 & 25.0 & 0.0 & 1.0 \\
\hline 5 & 20.0 & 36.0 & 1.0 & 1.0 \\
\hline 6 & 25.0 & 28.0 & 0.0 & 1.0 \\
\hline 7 & 32.0 & 25.0 & 0.0 & 1.0 \\
\hline 8 & 12.0 & 30.0 & 0.0 & 1.0 \\
\hline 9 & 349.0 & 220.0 & 15.0 & 2.0 \\
\hline 10 & 286.0 & 197.0 & 8.0 & 2.0 \\
\hline 11 & 369.0 & 332.0 & 23.0 & 2.0 \\
\hline 12 & 356.0 & 198.0 & 25.0 & 2.0 \\
\hline 13 & 298.0 & 207.0 & 20.0 & 2.0 \\
\hline 14 & 325.0 & 220.0 & 15.0 & 2.0 \\
\hline 15 & 325.0 & 225.0 & 12.0 & 2.0 \\
\hline 16 & 345.0 & 227.0 & 14.0 & 2.0 \\
\hline 17 & 109.0 & 73.0 & 3.0 & 3.0 \\
\hline 18 & 253.0 & 153.0 & 20.0 & 3.0 \\
\hline 19 & 83.0 & 75.0 & 8.0 & 3.0 \\
\hline 20 & 108.0 & 154.0 & 21.0 & 3.0 \\
\hline 21 & 107.0 & 220.0 & 27.0 & 3.0 \\
\hline 22 & 120.0 & 227.0 & 29.0 & 3.0 \\
\hline 23 & 275.0 & 125.0 & 12.0 & 3.0 \\
\hline 24 & 321.0 & 320.0 & 29.0 & 3.0 \\
\hline
\end{tabular}

Keterangan:

$1=$ Kelompok Kontrol,

2 = kelompok dosis $1 \mathrm{~g} / \mathrm{KgBB}$

$3=$ Kelompok dosis $2 \mathrm{~g} / \mathrm{KgBB}$ 
Tabel 2. Hasil Analisa Statistik Perbandingan antar Kelompok pengukuran uji efek Afodiasiaka

\begin{tabular}{|c|l|c|}
\hline \multicolumn{2}{|c|}{ Kelompok Perbandingan } & P \\
\hline \multirow{5}{*}{ Introduction } & Kontrol dan dosis $1 \mathrm{~g} / \mathrm{KgBB}$ & 0,012 \\
\cline { 2 - 3 } & Kontrol dan Dosis 2g/KgBB & 0,012 \\
\cline { 2 - 3 } & $\begin{array}{l}\text { Dosis } 1 \mathrm{~g} / \mathrm{KgBB} \text { dan Dosis } \\
2 \mathrm{~g} / \mathrm{KgBB}\end{array}$ & 0,012 \\
\hline \multirow{5}{*}{ Climbing } & Kontrol dan $1 \mathrm{~g} / \mathrm{KgBB}$ & 0,012 \\
\cline { 2 - 3 } & Kontrol dan Dosis $2 \mathrm{~g} / \mathrm{KgBB}$ & 0,012 \\
\cline { 2 - 3 } & $\begin{array}{l}\text { dosis } 1 \mathrm{~g} / \mathrm{KgBB} \text { dan Dosis } \\
2 \mathrm{~g} / \mathrm{KgBB}\end{array}$ & 0,161 \\
\hline \multirow{5}{*}{ Coitus } & Kontrol dan Dosis $1 \mathrm{~g} / \mathrm{KgBB}$ & 0,012 \\
\cline { 2 - 3 } & Kontrol dan Dosis 2g/KgBB & 0,012 \\
\cline { 2 - 3 } & $\begin{array}{l}\text { Dosis } 1 \mathrm{~g} / \mathrm{KgBB} \text { dan Dosis } \\
2 \mathrm{~g} / \mathrm{KgBB}\end{array}$ & 0,611 \\
\hline
\end{tabular}

Dari tabel di atas, dapat disimpulkan bahwa ekstrak kembang sepatu menimbulkan efek afrodisiaka dalam parameter pengukuran introduction, climbing dan coitus pada dosis 1 dan $2 \mathrm{~g} / \mathrm{KgBB}$, Namun dari hasil analisa terilhat bahwa untuk parameter climbing antara kelompok perlakuan 1 (dosis $1 \mathrm{~g} / \mathrm{KgBB}$ ) dan perlakuan 2 $($ dosis $2 \mathrm{~g} / \mathrm{KgBB})$ diperoleh nilai $\mathrm{p}=0,161$ $(\mathrm{p}>0,05)$ sehingga dapat dikatakan antara perlakuan 1 dan perlakuan 2 tidak berbeda bermakna sehingga dapat dikatakan bahwa perlakuan 1 dengan dosis $1 \mathrm{~g} / \mathrm{KgBB}$ sudah cukup untuk menghasilkan efek afrodisiaka pada parameter Climbing. Untuk parameter coitus antara kelompok perlakuan 1 (dosis $1 \mathrm{~g} / \mathrm{KgBB}$ ) dan perlakuan 2 (dosis $2 \mathrm{~g} / \mathrm{KgBB}$ ) diperoleh nilai $\mathrm{p}$ $=0,611(p>0,05)$ sehingga dapat dikatakan antara perlakuan 1 dan perlakuan 2 tidak berbeda bermakna sehingga dapat dikatakan bahwa perlakuan 1 dengan dosis $1 \mathrm{~g} / \mathrm{KgBB}$ sudah cukup untuk menghasilkan efek afrodisiaka pada parameter Coitus.

Terdapat 3 senyawa metabolit sekunder yang menurut penelitian terbukti memiliki aktivitas afrodisiaka. Senyawa tersebut adalah flavonoid, alkaloid dan saponin. Dalam aktivitasnya sebagai afrodisiaka, flavonoid berperan sebagai inhibitor PDE-5 atau phosphodiestrase type 5 (Ko et. al., 2004 dikutip dari Da Silva et. al, 2012). Alkaloid membantu relaksasi otot polos corpus cavernosum yang memicu terjadinya ereksi. Alkaloid juga meningkatkan pelepasan nitric oxide dari ujung saraf dan meningkatkan dilatasi pembuluh darah pada alat kelamin pria (Andini, 2014). Sedangkan saponin berperan dalam meningkatkan kadar LH dan FSH sekaligus dalam sintesis DHEA (dehydroepiandrosteron) sehingga meningkatkan kadar testoteron dalam tubuh dan memacu libido (Andini, 2014).

Bunga kembang sepatu pun memiliki kandungan senyawa metabolit flavonoid, alkaloid, dan saponin. Karena kandungan ketiga senyawa inilah yang membuat bunga kembang sepatu berkhasiat sebagai afrodisiaka. Obat sintesis untuk pengobatan disfungsi ereksi sampai saat ini masih mempunyai mekanisme kerja sebagai PDE-5 inhibitor. Dimana PDE-5 ini menghambat pembentukkan enzim cGMP (cyclic Guanosine Monophospate) yang berfungsi melebarkan pembuluh darah serta meningkatkan laju aliran darah sehingga menyebabkan terjadinya ereksi. Contohnya adalah sildenafil.

Afrodisiaka memiliki mekanisme kerja yang berbeda-beda. Diantaranya: (1) melalui peningkatan NO dan cGMP, (2) peningkatan LH dan FSH, (3) penurunan hormon prolaktin, (4) peningkatan hormon testoteron, dan (5) mekanisme saraf simpatis-parasimpatis. Dengan kata lain dapat dikatakan bahwa afrodisiaka bekerja secara sinergis untuk memicu terjadinya ereksi dengan mekanisme kerja yang berbedabeda. Demikian pula dengan yang terjadi pada ekstrak bunga kembang sepatu. Alkaloid, flavonoid, dan saponin seperti yang sudah dijelaskan sebelumnya memiliki mekanisme kerja yang berbeda-beda sebagai afrodisiaka. Sehingga untuk hasil yang maksimal, maka ketiga senyawa ini akan bekerja secara bersamaan di tempat yang berbeda dalam mekanisme kerja ereksi.

\section{SIMPULAN}

Dari percobaan dan pengamatan yang telah dilakukan dapat disimpulkan bahwa:

1. Bunga kembang sepatu memiliki efek sebagai afrodisiaka pada parameter pengukuran introduction dan climbing.

2. Dosis yang lebih efektif dalam menimbulkan efek afrodisiaka pada parameter introduction adalah $2 \mathrm{~g} / \mathrm{KgBB}$, Climbing dan coitus adalah $1 \mathrm{~g} / \mathrm{KgBB}$. 


\section{DAFTAR PUSTAKA}

Andini D, 2014, Potential of Katuk Leaf (Sauropus androgynus (L) Merr.) as Aphrodisiac, J Majority, 3(7), 17-22

Da Silva CV, Borges FM, Velozo ES, 2012, Phytochemistry of some Brazilian Plants with Aphrodisiac Activity, Phytochemicals-A Global Perspective of Their Role in Nutrion and Health, 307326.

Jadhav VM, Thorat RM, Kadam VJ, Sathe NS, 2009, Traditional medicinal uses of Hibiscus rosa-sinensis, Journal of Pharmacy Research 2009, 2(8), 12201222.
Muslichah S, 2011, Potensi Afrodisiak Kandungan Aktif Buah Cabe Jawa (Piper retrofractum Vahl) pada Tikus Jantan Galuh Wistar, J Agrotek, 5(2): 1732.

Widiani T, 2006, Efek Antifertilitas Ekstrak Akar Som Jawa (Talinum paniculatum Gaertn) pada Mencit (Mus musculus L) Jantan. Jurusan Biologi Fakultas MIPA Universitas Sebelas Maret Surakarta, Buletin Penelitian Kesehatan, Vol. 34, No.3; 2006: 119-12. 